\title{
The Visionary Views of Medical Masters of Yester Years on Nature's Norms Point to Present Prospects in the Target Therapy of Cancer
}

\section{Wilson IBOnuigbo*}

Medical Foundation and Clinic, 8 Nsukka Lane, P.O. Box 1792, Enugu 400001, Nigeria

*Corresonding autor: Medical Foundation and Clinic, 8 Nsukka Lane, P.O. Box 1792, Enugu 400001, Nigeria, Tel: +2348037208680; E-mail: wilson.onuigbo@gmail.com

Received date: July 16, 2014, Accepted date: November 24, 2014, Published date: December 1, 2014

Copyright: @ 2015 Onuigbo, et al. This is an open-access article distributed under the terms of the Creative Commons Attribution License, which permits unrestricted use, distribution, and reproduction in any medium, provided the original author and source are credited.

\begin{abstract}
Medical history substantiates the significant status of Nature In scientific communications. Therefore, this paper demonstrates that Nature's footsteps are veritably traceable in the microenvironment of the thoracic duct in lung cancer cases, with regard to the necrosis of the cells being transported in it. Accordingly, Nature gives notice that, if translational research is carried out on consenting patients, the resultant breakthrough will probably conduce to cancer cure.
\end{abstract}

Keywords: Lung cancer; History; Thoracic duct; Natural factor; Target therapy

\section{Introduction}

Since writing my embryonic paper on the history of cancer back in 1958 as regards Horner's syndrome [1]. I have over the years drawn attention to various aspects of cancer history. The latest paper [2] dealt with 27 old authors whose perception of lung cancer from 1818 to 1897 was of a cancer that anomalously failed to cross the midline to the opposite lung! This and other issues led me to develop the hypothesis that a hitherto unknown Factor was at work and that it is one that translational medicine can decode [3]. In this context, Inoted that the greats thought in terms of Nature's definite roles.Therefore, this long standing welcome aspect of history requires exposition.

\section{Historical Texts}

We go first to William Harvey [4] who wrote a letter to one Dr. R. Morison of France on 28th April, 1652. He asked thus: "Why may not the thoughts, opinions, and manners nowprevalent, many years hence return again, after an intermediate period of neglect?"

In the 1847 translation by Robert Willis of the Works of William Harvey proper, there is a petite problem presented thus: Nature is herself to be addressed; the paths she shows us are to be boldly trodden; for thus, and whilst we consult our proper senses, from inferior advancing to superior levels, shall we penetrate at length into the heart of her mystery.

Thereafter, he was more expansive as follows:

Nature is nowhere accustomed more openly to display her secret mysteries than in cases where she shows traces of her workings apart from the beaten track; nor is there any better way to advance the proper practice of medicine than to give our minds to the discovery of the usual law of nature, by the careful investigation of these rarerforms of disease.

William Gull [5] in his 1870 Harveian Oration also addressed his listeners on Nature! As he put it instructively, "what the student of nature's mysteries always needs to remember is that his position is viewing things from his own centre rather than from the centre. What he has chiefly to avoid is that discouragement does not pass into denial." In another Harveian Oration, Sir William Roberts [6] ruminated on the theme that "Science advances by a succession of discoveries." As he continued, "Each discovery constitutes a permanent addition to natural knowledge - and furnishes a post of vantage for, and a suggestion to, further discoveries." On his part, Julius Cohnheim [7], the great German pathologist, was forthright that autopsy findings " are all ina manner experiments instituted by nature, which we need only rightly interpret to get a clear idea of the causes, laws of growth, and significance of the tumour."

\section{Discussion}

Nature has clearly been identified above as a formidable figurein the literature of the history of cancer. What of the present age? I painted the pictures of the interpretation of Nature as follows:

(i) It is the mono-block formalin-fixation autopsy method that substantively reveals topography's importance in research [8]

(ii) It ensured the securement of the $45 \mathrm{~cm}$ long thoracic duct thus facilitating -with single microscope slides-the panorama of lung cancer cells travelling in this natural highway at the moment of death [9].

(iii) It led to the conclusion, among other results, that, in this microenvironment, the cancer cells clearly become necrotic when commingled with the erythrocytes [9].

(iv) It was hypothesized, therefore, that there must be a hidden natural facilitatorresponsible for this natural phenomenon, i.e., "ErythrocyteAssociated Necrosis Factor (EANF) [10].

(v) It was consequently suggested that, using the old method [11] of cannulating the duct, comes first. Next, there is combination of it with the new technique of intravitalvideomicroscopy [12].

Readily, the retrieval of lively cancer cells and necrotic cancer cells will provide the appropriate pabulum for timely anddelicate translational research. In all probability, this willidentify the aforesaid EANF and replicateit for targettherapy [3] 
(vi) It has led to the compilation, as a book 13 of 12 human models too research.

Moreover, thereisalso the general hoped for materialization in terms of using the human frame to enthrone cancer researches. In this context, the lowly positioned popliteal lymph node group has been harnessed for answering one quaintquestion, namely, "What happens to cancer cells which mustnaturally arrivethere by blood or by lymph as regards the age old researches on lung cancer metastasis"? [14].

\section{Conclusion}

Background information has been provided above regarding the historical role of Nature in scientific discoveries. Half a century ago [15], I boldly calculated in The Lancet, on the basis of the uniquely placed glomerulus, that the rate of cancer colonization of it, during life, was probably of the order of 1 per 100,000. Thereafter, I concluded propitiously thus:

In examining carefully and questioning critically the efficacy of the circulating cancer cells as invasive agents, patterns of metastasis seen in man himself must be mapped out fully. In particular, there is need to compare blood-borne and lymph-borne cancer cells to discover any exploitable differences between thetwomediadifferences which may have therapeutic potentialities.

Potentialities have now been identified as regards the human thoracic duct vis-a-vis autopsied lung cancer cases. Therefore, going by the trends of Nature,the future portends success in the hopeful field of target therapy. In sum, this should be possible through recondite retrieval and replication of that natural necrosis phenomenon which, hitherto existed unrecognized and unchallenged in the thoracic duct of the cancer patient!

\section{References}

1. Onuigbo, WIB John Reid (1809-1849) and Horner's syndrome. Scottish Medical Journal 3:218-220.

2. Onuigbo WI (2014) Anomalous lung cancer cell carriage: a historical review with present prospects. Int J Surg 12: 734-736.
3. Onuigbo WI (2014) Is there a natural translational system suitable for the target therapy of lung cancer? Translational Medicine, in press.

4. Willis R (1847) Translation from Latin of The works of William Harvey. Lond: Sydenham Society 186-616.

5. Gull W(1870) The Harveian Oration. Lond: Churchill, 1870, p. 12.

6. Roberts W (1897) The Harveian Oration. Lond: Smith, Elder \& Co.

7. Conheim J (1889) Lectures on general pathology. Transl from the 2nd German Ed by A.B. Mckee. Section 1. Lond: New Sydenham society, p. 14.

8. Onuigbo WI (1963) A mono-block formalin-fixation method for investigating cancer metastasis. Z Krebsforsch 65: 209-210.

9. Onuigbo WI (1967) The carriage of cancer cells by the thoracic duct. $\mathrm{Br}$ Cancer 21: 496-500.

10. Onuigbo WI (2013) Nature's necrosis factor when associated with erythrocytes may not only explain the surprises in lung cancer metastases but also suggest target therapy. Hypotheses 80: 698-700.

11. Mittleider D, Dykes TA, Cicuto KP, Amberson SM, Leusner CR (2008) Retrograde cannulation of the thoracic duct and embolization of the cisterna chyli in the treatment of chylous ascites. J VascIntervRadiol 19: 285-290.

12. Chambers AF, MacDonald IC, Schmidt EE, Koop S, Morris VL, et al. (1995) Steps in tumor metastasis: new concepts from intravitalvideomicroscopy. Cancer Metastasis Rev 14: 279-301.

13. Onuigbo, WIB (2011) Human models in cancer metastasis research, Saarbrucken, Germany: LAP LAMBERT Academic Publishing GmbH \& Co. KG.

14. Onuigbo WIB (2010) The popliteal lymph node group as a naturally positioned model for research on lung cancer metastasis. Journal of Cancer Research and Experimental Oncology2: 27-28.

15. Onuigbo WI (1963) An Index of The Fate of Circulating Cancer Cells. Lancet 2: 828-831. 